\title{
Distribution, diversity, mesonotal morphology, gallery architecture, and queen physogastry of the termite genus Calcaritermes (Isoptera, Kalotermitidae)
}

\author{
Rudolf H. Scheffrahn \\ Fort Lauderdale Research and Education Center, University of Florida, 3205 College Avenue, Davie, FL \\ 33314 U.S.A. \\ Corresponding author: Rudolf H. Scheffrahn (rhsc@ufl.edu) \\ Academic editor: Michael Engel| Received 11 May 2011 | Accepted 22 August 2011 | Published 21 November 2011 \\ Citation: Scheffrahn RH (2011) Distribution, diversity, mesonotal morphology, gallery architecture, and queen \\ physogastry of the termite genus Calcaritermes (Isoptera, Kalotermitidae). In: Engel MS (Ed) Contributions Celebrating \\ Kumar Krishna. ZooKeys 148: 41-53. doi: 10.3897/zookeys.148.1505
}

\begin{abstract}
An updated New World distribution of the genus Calcaritermes is given along with photographs and a key to the New World species outside Mexico. Calcaritermes recessifrons is found to be a junior synonym of $C$. nigriceps. Except for $C$. temnocephalus, pseudergates of the other seven studied Calcaritermes species possess a mesonotal rasp. The rasps suggest a role in propagation of microbes on gallery surfaces and microbial infusion below the wood surface. Calcaritermes temoncephalus is shown to have an unusually large physogastric queens for a kalotermitid and several species produce large eggs.
\end{abstract}

\section{Keywords}

Neotropical distribution, species synonymy, field photography, taxonomic soldier key, mesonotal rasp, microbial symbiosis, queen physogastry, eggs

\section{Introduction}

In his monumental revision of the family Kalotermitidae, Krishna (1961) formed the current taxonomic definition of the termite genus Calcaritermes (Snyder 1925). Krishna (1961) separated Calcaritermes from all other genera by the diagnostic enlargement of the outer spine ("spur" sensu Snyder 1925b) of the fore tibia relative to the other two tibial spines. Soldiers also possess a dark, rather smooth, and cylindrical head cap-

Copyright Rudolf H. Scheffrahn. This is an open access article distributed under the terms of the Creative Commons Attribution License, which permits unrestricted use, distribution, and reproduction in any medium, provided the original author and source are credited. 
sule. Calcaritermes is a basal group within the Kalotermitidae (Legendre et al. 2008) and is not closely related to the sympatric Cryptotermes which also possess phragmotic dark-headed soldiers. Krishna 1961, however, could not morphologically distinguish Calcaritermes alates from those of the genus Glyptotermes. Even so, Emerson (1969) described C. vetus from a fossilized alate in amber collected in the Simojovel region of Chiapas, Mexico. Emerson based his generic assignment on the similarity of the fossil to that of $C$. temnocephalus and its range in southeastern Mexico. The most recent review of Calcaritermes distribution was also provided by Emerson (1969).

As with most non-pest termite genera, details of the ecology and bionomics of the Calcaritermes are completely unknown. Almost all that is published about Calcaritermes relates to identification of preserved specimens for faunal surveys (e.g. Scheffrahn et al. 2005 and part of this paper). The only research involving Calcaritermes biology stems from two studies: one of their protist gut fauna (Gile et al. 2010) and the other of alate flight in forest canopy (Bourguignon et al. 2009).

In the current paper, the New World distribution and diversity of Calcaritermes is revised based on material in the University of Florida collection. I use field photography to show the live habitus of castes of seven Calcaritermes species and depict eight soldiers using montage photography of preserved material. I also reassess the mesonotal "rasp" of pseudergate castes of Calcaritermes and provide an example of extreme queen physogastry in the Kalotermitidae. Finally, I describe the atypical feeding galleries of this genus and hypothesize a relationship between gallery architecture and the mesonotal rasp in terms of microbial symbiosis.

\section{Material and methods}

A total of 214 colony samples of Calcaritermes from 122 localities (Fig. 1) were collected between 1996 and 2010 and identified by the author from original descriptions and comparisons. These samples are included in the University of Florida (UF) Termite Collection, Fort Lauderdale Research and Education Center, Davie, Florida. This collection houses over 34,000 samples, mostly from the Caribbean Basin, which the author and his colleagues have amassed since 1986. The findings herein are a direct result of field observations made while collecting Calcaritermes during various survey expeditions.

Field photographs (Figs 2, 4E, 4F, and 5) were taken with a Nikon Coolpix S7c digital camera set to macro and flash mode. Specimens were usually photographed in a $5.5 \mathrm{~cm}$ dia. plastic Petri dish bottom lined with manila folder cardboard although natural substrate (Figs 3D and 3I) was sometimes suitable. Figures 3 and 4C were taken as multilayer montages using a Leica M205C stereomicroscope controlled by Leica Application Suite version 3 software. Montage specimens were taken from 85\% ethanol and suspended in a pool of Purell ${ }^{\circ}$ Hand Sanitizer to position the specimens in a transparent plastic Petri dish. Mesonotal rasps (Figs 4A and B) were slide-mounted with PVA mounting medium (BioQuip Products, Inc) and photographed with an Olympus BH-2 compound microscope fitted with phase contrast optics. Figure 3D 
was taken of a pseudergate that was freshly killed by desiccation and photographed with a Hitachi 4700 FESEM scanning electron microscope at 3-5 kV.

\section{Results and discussion}

\section{Distribution}

Calcaritermes is primarily a neotropical genus with the exceptions of a relic nearctic species, C. nearcticus Snyder, 1933, found from central and northeastern Florida to southeastern Georgia (Scheffrahn et al. 2001) and an anomalous indomalaysian congener, C. krishnai (Maiti and Chakraborty) known from Great Nicobar Island (Roonwal and Chhotani 1989) and Papua New Guinea (Y. Roisin, unpublished data). The current New World distribution of Calcaritermes is given in Fig. 1. Literature localities in Fig. 1 include C. colei Krishna from San Luis Potosi, Mexico and C. snyderi Krishna from El Salvador (Krishna 1962), C. imminens from Colombia (Snyder 1925b), C. parvinotus Light from Colima, Mexico (Light 1933) and from Chamela, Mexico (Nickle and Collins 1988) and C. rioensis from Brazil (Krishna 1962, Reis and Cancello 2007). Emerson's 1969 localities for C. guatemalae (Tabasco region of Mexico) and C. nigriceps (central Colombia) not mapped in Fig. 1 because they were deemed too vague.

\section{Nomenclatural revisions}

Krishna (1962) redescribed C. temnocephalus (Silvestri 1901) from types collected in Venezuela (Silvestri 1903) and additional material from Trinidad. The type locality, Las Trincheras $(10.31,-68.09)$, Carabobo State, is in the vicinity of Caracas where Frederik Vilhelm August Meinert collected insects in 1891 (Reuter 1904) of which the termites were studied by Silvestri $(1901,1903)$. In 2008, we collected all castes of a Calcaritermes sp. at P.N. San Sebastián, Carabobo, Venezuela (10.402, -68.000, elev. $105 \mathrm{~m}$ ). Our material matched Krishna's 1962 redescription of C. temnocephalus and substantiates our earlier synonymy that $C$. fairchildi is a junior synonym of $C$. temnocephalus (Scheffrahn et al. in press). Specifically, the description of $C$. fairchildi (=thompsonae) (Snyder 1926b, 1926c) from Costa Rica (Fig. 1) also compares favorably with our Venezuela sample. I have compared 50 colony series of $C$. temnocephalus from Guadeloupe to Ecuador and Belize. C. temnocephalus is unique among congeners in the UF collection (species shown in Fig. 3) because pseudergate castes do not have a mesanotal rasp and also lack the concavity of the posterior margin of the pronotum (Figs $4 \mathrm{E}, 5 \mathrm{C}$ ). Imagos of $C$. temnocephalus are unique among those described in the genus in that they are orange-brown in body coloration and have hyaline wings (Fig. 2B, 5C). The next lightest imago is $C$. brevicollis with a medium brown dorsal coloration and lightly pigmented wings. All eight other described Calcaritermes imagos are dark brown to blackish and have smoky wings (e.g., Fig. 2D, 2I). 
Snyder (1925b) described C. recessifrons from one soldier and a series of alates (type locality Cincinnati, 11.10, -74.08, Fig. 1) collected by W. M. Mann during his expedition to Colombia. In 2009, we surveyed termites near the type locality for C. recessifrons ("above" Minca 11.126, -74.120 , elev. $712 \mathrm{~m}$ ) and collected several colony samples of Calcaritermes there. Our material matched Snyder's description of C. ressesifrons. The description of C. nigriceps (Emerson 1925) from British Guiana (Fig. 1, now Guyana) also compared favorably with our sample. Further comparison of Calcaritermes specimens collected from Grenada to Panama (Fig. 1) confirmed that $C$. recessifrons is a junior synonym of $C$. nigriceps as previously reported by Scheffrahn et al. (in press). C. nigriceps soldiers are unique among congeners in the UF collection as the frontal furrow is shallow and unsculptured (Fig. 3C). Cincinnati, Colombia, is also the type locality of $C$. imminens (Snyder 1925b); however, we were unable to collect this distinctive medium-sized species in which the soldier has an overhanging frons. Table 1 lists the current New World species of Calcaritermes and their type localities.

\section{Key to Calcaritermes in the UF collection based on the soldier or pseudergate caste}

$1 \quad$ Pseudergates (pseudergates without large wing buds) lack mesonotal rasp or concave posterior margin of pronotum; soldier with frontal furrow rather even in depth extending length of frons at a shallow angle, frontal lobes with distinct elongate rugosity (Fig. 3G)

C. temnocephalus Pseudergates with mesonotal rasp and concave posterior margin of pronotum (Fig. 4C), soldier unlike above 2 Soldier maximum head width $1.4 \mathrm{~mm}$ or more, head capsule elongate; furrow rugose; frontal lobes clearly not overhanging frons (Fig. 3A)

Soldier maximum head width less, or much less than $1.4 \mathrm{~mm}$, head variable.... 3 Head capsule somewhat to clearly elongate (Figs 3C, 3D, 3E, 3H) Head capsule truncate, mandibles short (Figs 3B, 3F) Frontal furrow unsculptured; frontal lobes smooth; lobes obtuse in angle ca. $145^{\circ}$ (Fig. 3C)

Frontal furrow and lobes with sculpturing; lobes form angle ca. $90-100^{\circ}$ (Figs $3 \mathrm{D}, 3 \mathrm{E}, 3 \mathrm{H})$

Frontal lobes rounded, ovoid depression near center of lobes (Fig. 3H)

C. snyderi

Frontal lobes more acutely pointed, no ovoid depression near center of lobes (Figs 3D, 3E)

Larger species, maximum head width $1.2-1.3 \mathrm{~mm}$, frontal lobes with slightly overhanging tips, neotropical distribution (Fig. 3E)

C. emarginicollis Smaller species, maximum head width $1.1 \mathrm{~mm}$, frontal lobes evenly angled, Nearctic distribution only (Fig. 3D) 


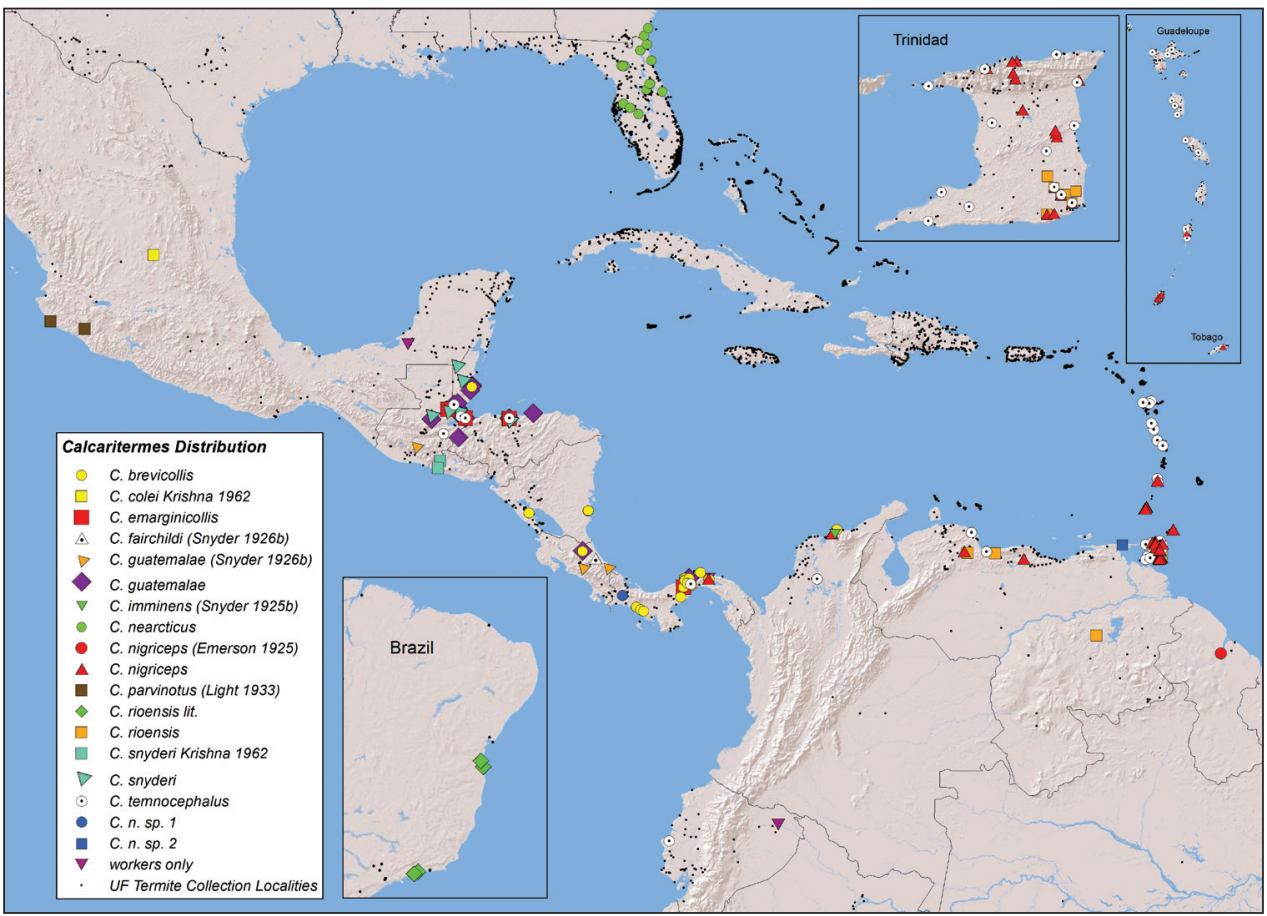

Figure I. Calcaritermes distribution in the New World. Species and junior synonym names followed by citations or by "lit" are mapped from citation data only. All other species localities are mapped from records of the University of Florida Termite Collection.

Table I. Revised New World list of Calcaritermes Snyder, 1925 and type localities.

\begin{tabular}{l|l}
\hline C. brevicollis (Banks 1918) & Panama* $^{*}$ \\
\hline C. colei Krishna 1962 & San Luis Potosi \\
\hline C. emarginicollis (Snyder 1926a) & Rio Chinilla, Canal Zone, Panama* \\
\hline C. guatemalae (Snyder 1926b) & Mixco, Guatemala* \\
\hline C. imminens (Snyder 1925b) & Cincinnati, Colombia \\
\hline C. nearcticus (Snyder 1933) & Clay County, Florida* \\
\hline C. nigriceps (Emerson 1925) & Kartabo, Guyana* \\
\hline C. parvinotus (Light 1933) & Colima, Mexico \\
\hline C. rioensis Krishna 1962 & Ihla Grande, Rio de Janeiro, Brazil* \\
\hline C. snyderi Krishna 1962 & Volcan de Santa Ana, El Salvador* \\
\hline C. temnocephalus (Silvestri 1901) & Las Trincheras,Venezuela (see text)* \\
\hline Undescribed sp. 1 & Boquette, Panama* \\
\hline Undescribed sp. 2 & Paria Pennisula,Venezuela* \\
\hline
\end{tabular}

* Specimens housed in UF collection. 
$7 \quad$ Frontal lobes nearly overhanging frons; raised well above vertex; distinct ovoid depression in center of lobes (Fig. 3F) ............................ C. brevicollis

- $\quad$ Frontal lobes not overhanging frons; almost even with vertex; lacking ovoid depression in center of lobes (Fig. 3B).....

C. rioensis

\section{Mesonotum morphology}

Mandible dentition of pseudergate or nymphal castes has been used for generic grouping of some Kalotermitidae (Krishna 1961), but for most genera, these weak and often overlapping characters by themselves lead to tenuous or uncertain identifications. In describing the imago and immature forms of $C$. emarginicollis from Costa Rica, Snyder (1925a) was first to observe and depict (Snyder's Figs 2, 4) that the mesonotum of the brachypterous nymph had an "aspirate or rugose area" while in the presoldier caste, he noted that the aspirate area of the mesonotum was elevated. Snyder (1925b, 1926ab), Light (1933), and Krishna (1962) described eight more Calcaritermes species, but the mesonotal rugosity was not mentioned again for any caste until Miller (1943) reported that nymphs of $C$. nearcticus had a "slightly raised median mesonotal area upon which appear numerous aspirities". In Krishna's 1961 revision of the Kalotermitidae, the mesonotal character was not mentioned.

These mesonotal "rasps" were found on all apterous pseudergates, early stage brachypterous nymphs, and most soldiers of Calcaritermes for species in the UF Collection (Table 1) with the exception of $C$. temnocephalus in which the rasp is absent. Under magnification, it was observed that each of these rasps actually consist of a single layer of slightly overlapping spatulate scales with basal attachments at their anterior ends (Figs 4A, 4B, 4D). The mesonotal rasps have a midline divide and form an elevated mound raised above the remainder of the dorsum (Fig. $4 \mathrm{C}$, right). The posterior margin of the pronotum of all eragtoid/nymphoid castes, except again C. temnocephalus, has a posterior marginal concavity that partially surrounds the anterior of the rasp (Fig. 4C, arrow). The pronotum is steeply angled toward the head anterior to the rasp (Fig. $4 \mathrm{C}$, right). The scale patterns and lateral profile of the rasps vary somewhat among species (e.g., Figs 4A, 4B) but no species-specific morphology was investigated in this study. No rasp was found on any mature reproductive and the robustness of the rasp was inversely proportional to wing bud size disappearing when the nymphs were one molt from adulthood. The mesonotal rasp is the first external character to provide a diagnostic, generic identification of an immature kalotermitid.

Microscopic examination of the mesonotal rasps from ethanol-preserved specimens did not reveal microbial material around the scales. However, when live specimens of $C$. nearcticus were prepared for SEM without cleaning or rinsing, an organic (microbial?) paste was observed between the scales (Fig 4D).

Queen physogastry. Over the years, I have observed hundreds of mature queens in kalotermitid nests but was struck by the extreme queen physogastry in C. temnocephalus. On 26 May 2008, two colonies of $C$. temnocephalus were collected by the UF 


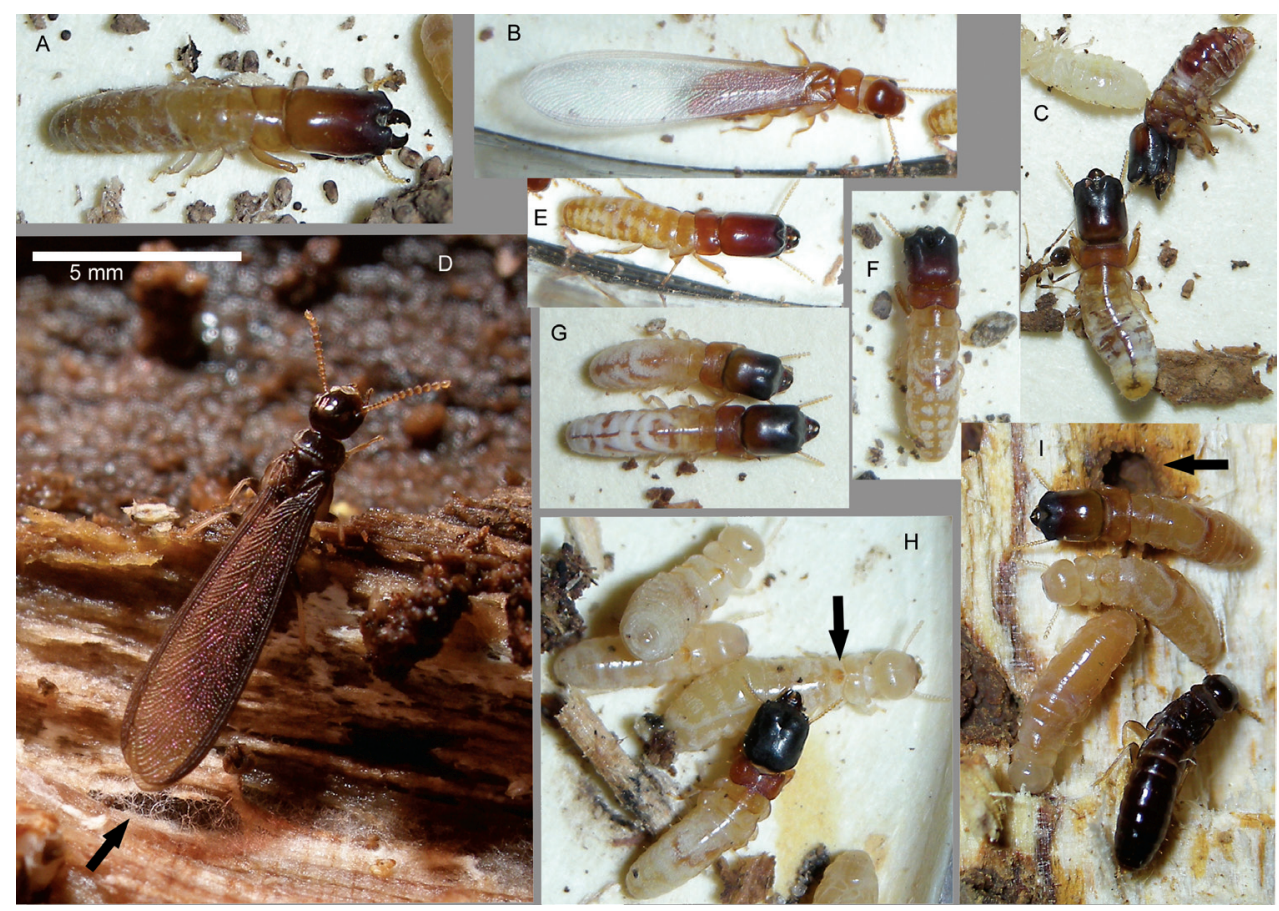

Figure 2. Photographs of live Calcaritermes specimens taken during collection. A Soldier of C. guatemalae, Honduras B Alate of C. temnocephalus, Venezuela C Soldiers of C. snyderi Honduras D Alate of C. guatemalae, Belize (arrow denotes fungal hyphae growing in gallery) E Soldier of $C$. temnocephalus, Venezuela $\mathbf{F}$ Soldier of $C$. brevicollis, Colombia $\mathbf{G}$ Two soldiers from the same colony of $C$. nigriceps, Colombia $\mathbf{H}$ Soldier and pseudergates of $C$. rioensis, Venezuela (arrow denotes mesonotal rasp of pseudergate) I Soldier, dealate, and pseudergates of $C$. nearcticus, Florida (arrow denotes fungal staining around gallery). All images to same scale.

survey team at Silva Seco de Capadare, Guiermo, Venezuela (11.154, -68.590, elev. $58 \mathrm{~m}$ ). Both colonies were large and occupied rather sound wood from which a mature primary queen was removed (Fig. 4E). The extent of physogastry of these queens is what is typically observed in the Rhinotermitidae or Termitidae in which the intersegmental membrane stretches well beyond the width of the tergites or sternites. Typically the extended intersegmental membrane in primary queens of the Kalotermitidae is narrower than the width of adjacent abdominal sclerites, but in the C. temnocephalus queens, the membrane is much wider than the sclerites. Eggs from one of the $C$. temnocephalus colonies (Fig. 4E, arrow) and from a C. brevicollis colony in Panama (Fig. 4F, arrows) also appeared disproportionally large compared to other kalotermitids.

Nests. Calcaritermes colonies infest damp or wet wood, usually in the shade of forest canopy. At ground level, populations are never plentiful in a given area. However, Roisin et al. (2006) found that the preponderance of C. brevicollis colonies in a Panamanian rain forest were occupying dead branches $10 \mathrm{~m}$ or higher above the ground. 

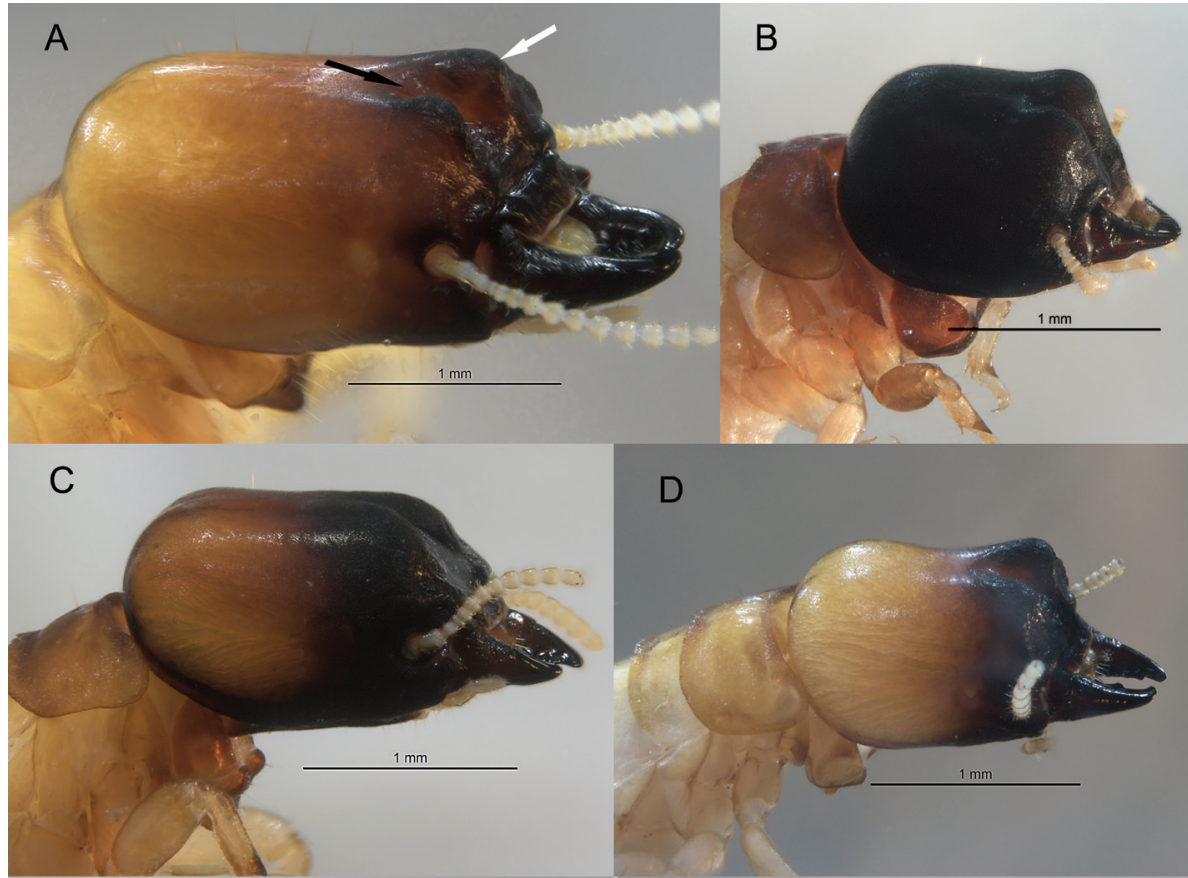

D

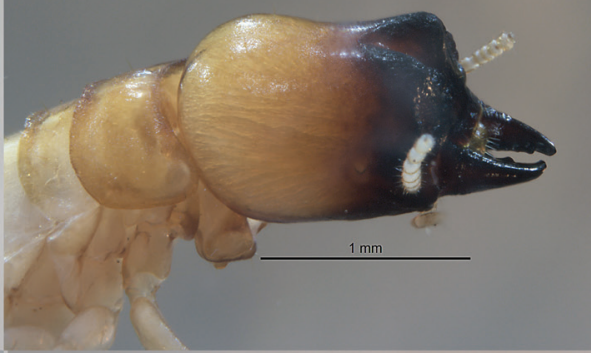

E

$\mathrm{F}$
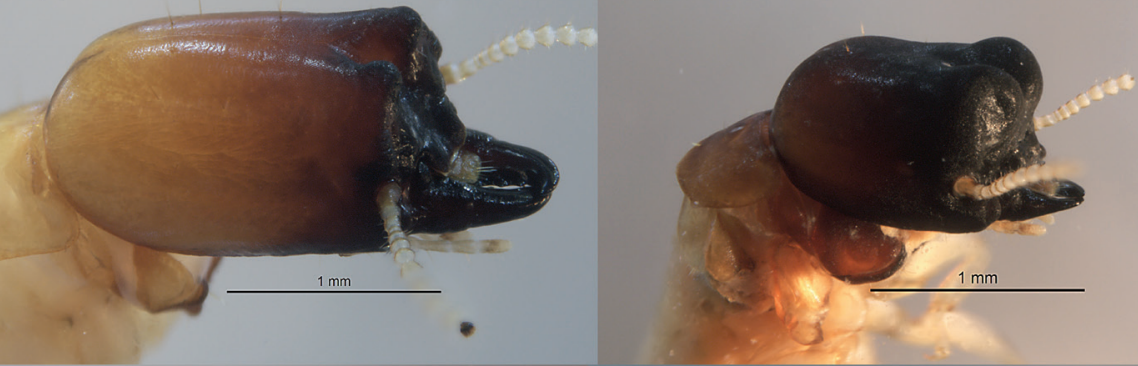

G

$\mathrm{H}$
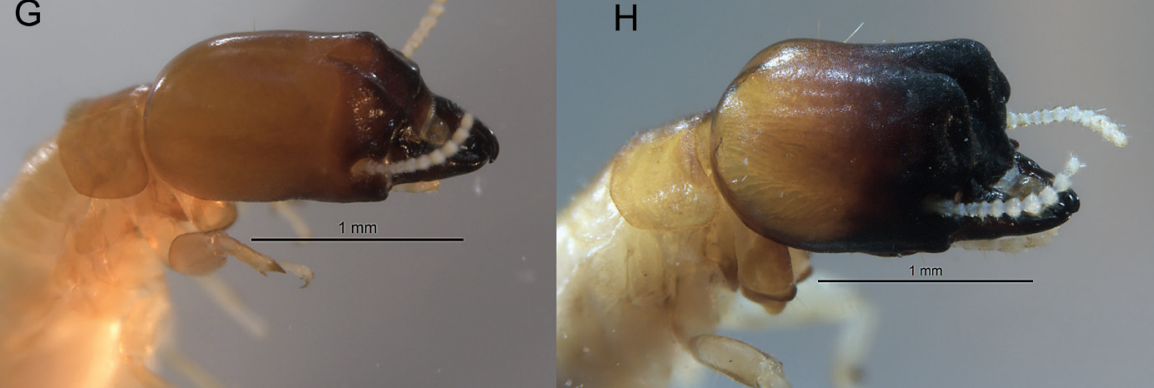

Figure 3. Oblique view of Calcaritermes soldiers from the University of Florida collection. A C. guatemalae, Honduras (black arrow shows orientation of frontal furrow, white arrow points to frontal lobe) B $C$. rioensis, Trinidad. C C. nigriceps, Trinidad D C. nearcticus, Florida E C. emarginicollis Honduras $\mathbf{F} C$. brevicollis, Nicaragua $\mathbf{G}$ C. temnocephalus, Guatemala $\mathbf{H}$ C. snyderi, Guatemala. Enlarge outer tibial spines visible in B and G. Photos to same scale. 


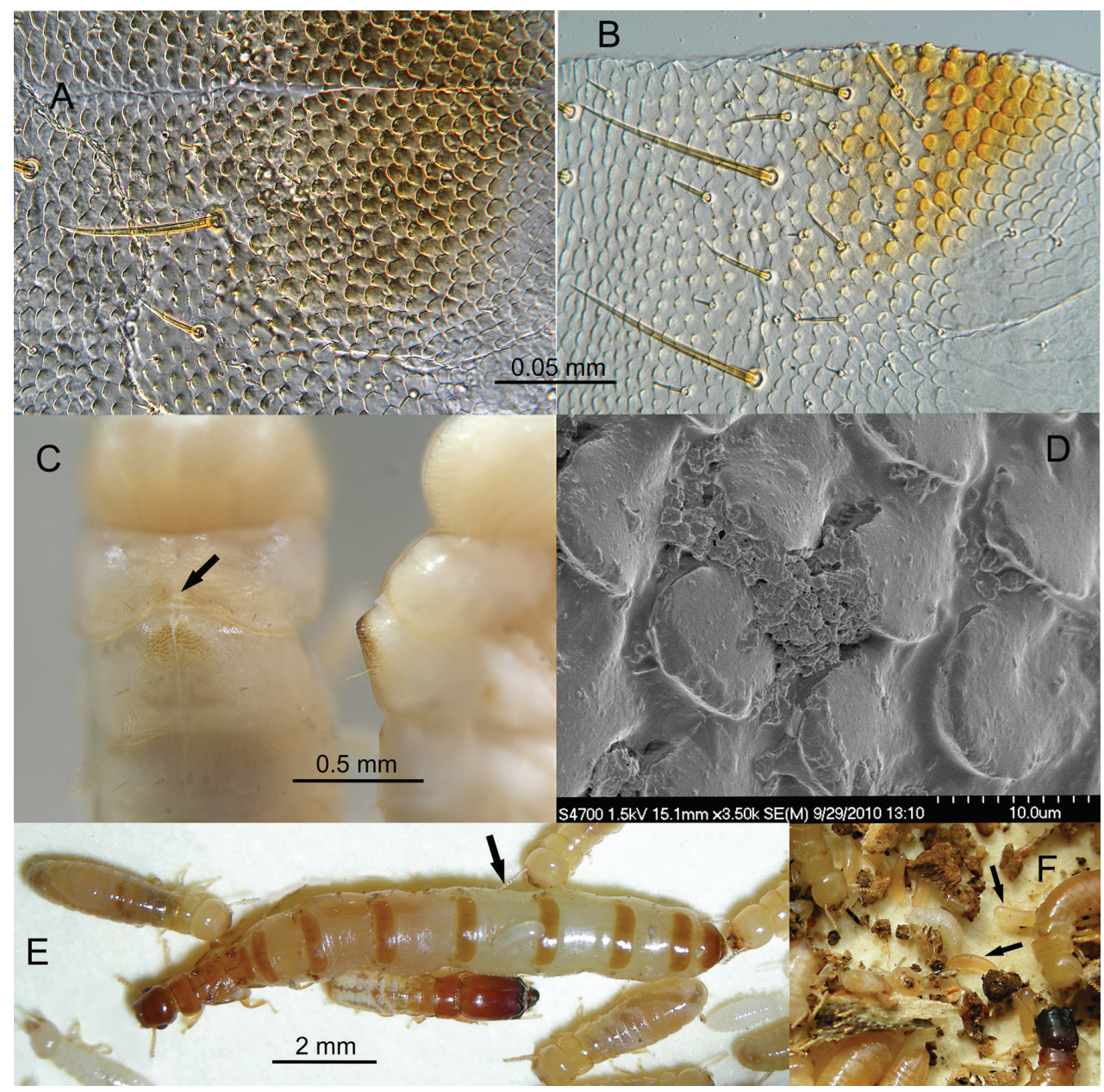

Figure 4. A Light micrograph of partial mesonotal rasp of $C$. nearcticus pseudergate from an ethanolpreserved specimen. Mid-line is horizontal near top of figure B Micrograph of half of mesonotal rasp of $C$. brevicollis pseudergate. Rasp is separated at the mid-line C Dorsal and lateral view of rasps on C. brevicollis pseudergates (arrow denotes concavity of posterior margin of pronotum to accommodate elevation of the rasp) D SEM of rasp of $C$. nearcticus from an unrinsed, freshly prepared specimen $\mathbf{E}$ Physogastric queen and other castes of $C$. temnocephalus (arrow denotes egg on queen dorsum) F Eggs (arrows amongst nest debris) of C. brevicollis, Colombia.

Workers and soldiers move rather slowly compared to most other kalotermitids, but in contrast, the alates flutter in hyperkinetic fashion as soon as their galleries are opened. Bourguignon et al. (2009) collected all dispersing C. brevicollis alates during March to June in flight intercept traps. No alates were attracted to light traps indicating that $C$. brevicollis, and probably the other dark-colored species, are daytime flyers.

The gallery system of Calcaritermes differs from other kalotermitids in several distinct ways. First, the galleries are narrow and tubular, maybe allowing only two termites to pass at one time. The galleries are spaced rather far apart in the wood matrix, thus 


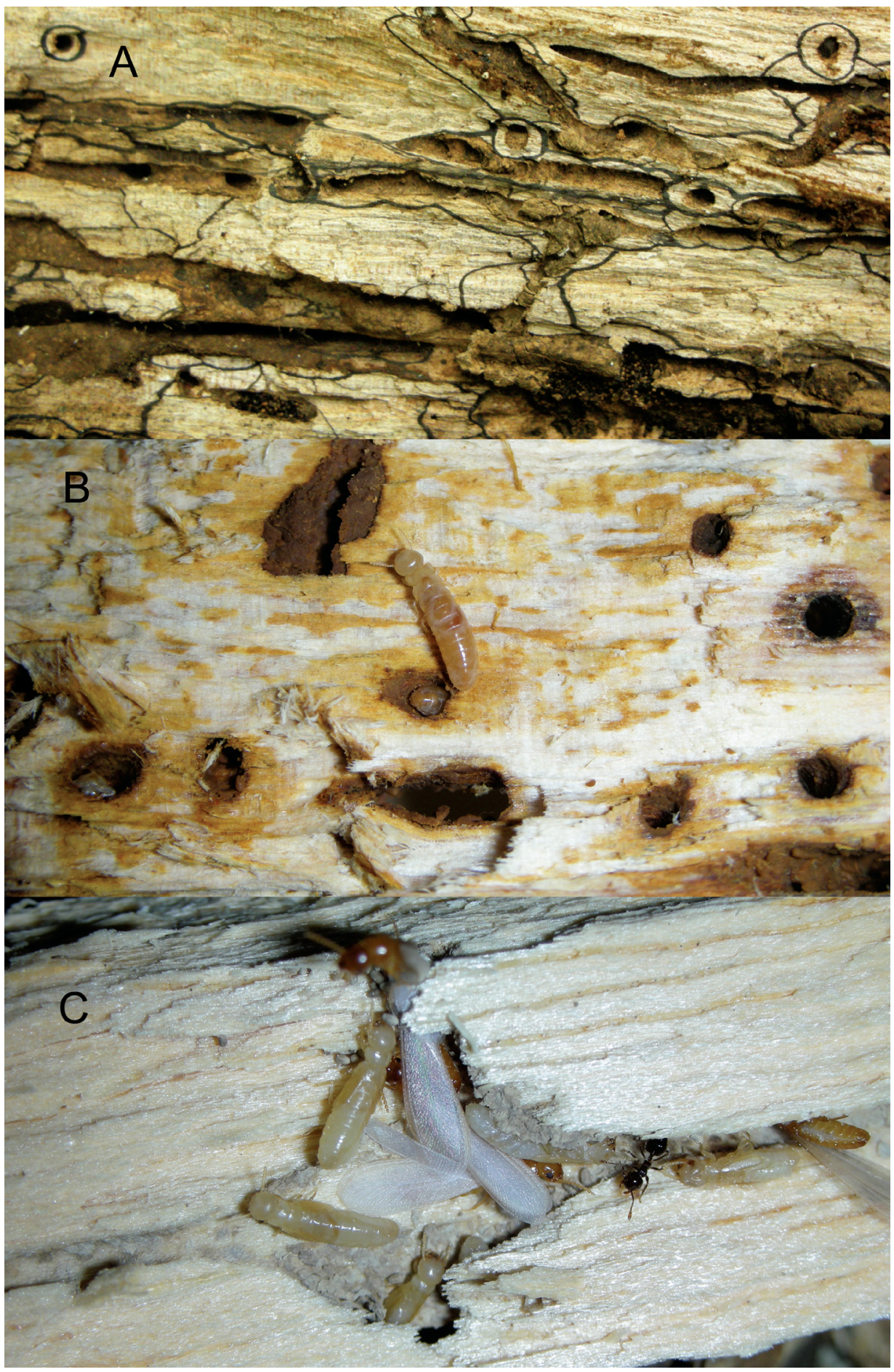

Figure 5. A C. nigriceps galleries exposed in Colombia B C. nearcticus galleries in oak wood, Florida C C. temnocephalus galleries in Venezuela. Images not to same scale. 
occupying a relative small volume of the colonized member (Figs 5A, 5B). Secondly, the galleries contain very few loose fecal pellets, but gallery surfaces are generously lined with what appears to be a moist fecal/microbial? paste (Figs 5A, 5B, 5C). Miller (1949) noted that $C$. nearcticus "lines some of its galleries with a coating of brownish material". Thirdly, the peripheries of the galleries are stained or exhibit halos suggesting fungal infection emanating from the gallery surfaces into the wood at varying depths (Figs 5A, 5B). Again, the exception is C. temnocephalus which infests wood in open, often dryer conditions, had less fecal coating and microbial growth (Fig. 5C) in their galleries.

Given the mesonotal rasp, the low volume of wood excavated, gallery coating, and peripheral gallery staining, one can hypothesize that Calcaritermes derives some nutrition via a symbiotic relationship with microbes growing on the surface of their galleries. The rasp may be used by foragers to inoculate gallery surfaces with fungal or bacterial spores analogous to the mycangium (Stone et al. 2007) found in bark beetles (Scolytinae). Unlike the mycangia of adult beetles, Calcaritermes adults (alates) show no obvious external structure for horizontal transfer of spores to new nesting sites although alimentary storage is a possibility. So whether Calcaritermes, like bark beetles, have some form of external association with microorganism (Gilbertson 1984) or actually rely on symbiotic mycophagy (Harrington 2005) remains to be studied.

\section{Acknowledgements}

I thank Kumar Krishna for setting the standard for impactful and high quality publications throughout his splendid career as a termite taxonomist. I am indebted to many contributors of material to the UF Termite Collection. I am especially grateful to the following termite survey expedition members: James A. Chase and John R. Mangold (original members, 1991-present), Julian de la Rosa Guzman (1991-1995), Jan Krecek (1994-present), Paul Ban (deceased, 1994-2009), Vinda Maharajh (deceased, 19962008), Yves Roisin (1997), John Warner (2001-2003), Tom Nishimura (2002-present), Bayardo Herrera and Jorge Moreno (2004), Rob Giblin-Davis and Natsumi Kanzaki (2005), Bob Setter and Tim Myles (2006-present), Brian Bahder (2006-2007), Jose Perozo (2007-2009), Solange Issa (2008) and Juan Saldarriaga (2009). Their enthusiasm, field expertise, and hard work has brought about many discoveries among the rich termite fauna of the southern Neactic and the Caribbean Basin. I thank Terminix International for funding much of our travel expenses since 2004. Many thanks to Erick James, Botany Department, University of British Columbia for Fig. 4C. The reviews by Jan Krecek and Seemanti Chakrabarti were most helpful.

\section{References}

Banks N (1918) The termites of Panama and British Guiana. Bulletin of the American Museum of Natural History 38: 659-667. 
Bourguignon T, Leponce M, Roisin Y (2009) Insights into the termite assemblage of a neotropical rainforest from the spatio-temporal distribution of flying alates. Insect Conservation and Diversity 2: 153-162.

Emerson AE (1925) The termites from Kartabo, Bartica District, British Guiana. Zoology 6: 291-459.

Emerson AE (1969) A revision of the Tertiary fossil species of the Kalotermitidae (Isoptera). American Museum Novitates 2359: 1-57.

Gilbertson RL (1984) Relationships between insects and woodrotting basidiomycetes. In: Wheeler Q, Blackwell M (Eds) Fungus-Insect Relationships, Perspectives in Ecology and Evolution. Columbia University Press, New York, 130-165.

Gile GH, James ER, Scheffrahn RH, Carpenter KJ, Harper JT, Keeling PJ (2010) Molecular and morphological analysis of the Calonymphidae with a description of Calonympha chia sp. nov., Snyderella kirbyi sp. nov., Snyderella swezyae sp. nov., and Snyderella yamini sp. nov. International Journal of Systematic and Evolutionary Microbiology. doi: 10.1099/ ijs.0.028480-0

Harrington TC (2005) Ecology and evolution of mycophagous bark beetles and their fungal partners. In: Vega FE, Blackwell M (Eds) Ecological and Evolutionary Advances in InsectFungal Associations. Oxford University Press, 257-291.

Krishna K (1961) A generic revision and phylogenetic study of the family Kalotermitidae (Isoptera) Bulletin of the American Museum of Natural History 122: 303-408.

Krishna K (1962) New species and a hitherto undescribed imago caste of the genus Calcaritermes Snyder (Isoptera, Kalotermitidae) American Museum Novitates 2098: 1-13.

Legendre F, Whiting MF, Bordereau C, Cancello EM, Evans TA, Grandcolas P (2008) The phylogeny of termites (Dictyoptera: Isoptera) based on mitochondrial and nuclear markers: Implications for the evolution of the worker and pseudergate castes, and foraging behaviors. Molecular Phylogenetics and Evolution 48: 615-627.

Light SF (1933) Termites of western Mexico. University of California Publications in Entomology. 6: 79-152+11 plates.

Miller EM (1943) The soldier and nymphal forms of Kalotermes (Calcaritermes) nearcticus Snyder. Proceedings of the Florida Academy of Sciences 6: 5-8.

Miller EM (1949) A handbook on Florida Termites. University of Miami Press, Coral Gables, Florida, 30 pp.

Nickle DA, Collins MS (1992) The termites of Panama (Isoptera). In: Quintero D, Aiello A (Eds) Insects of Panama and Mesoamerica, selected studies. Oxford University Press, New York, 208-241.

Reis YT, Cancello EM (2007) Riqueza de cupins (Insecta, Isoptera) em áreas de Mata Atlântica primária e secundária do sudeste da Bahia. Iheringia Série Zoologia Porto Alegre 97: 229-234.

Reuter OM (1905) Capsidae in Venezuela a D:o D:re Fr. Meinert collectæ enumeratæ novaeque species descriptæ. Öfversikt af Finska Vetenskaps-Societetens Förhandlingar XLVII 19: 1-39+1 plate.

Roisin Y, Dejean A, Corbara B, Orivel J, Samaniego M, Leponce M (2006) Vertical stratification of the termite assemblage in a neotropical rainforest. Oecologia 149: 301-311. 
Roonwal ML, Chhotani OB (1989) The fauna of India and the adjacent countries: Isoptera (termites), Volume 1. Zoological Survey of India, Calcutta, $672 \mathrm{pp}$.

Scheffrahn RH, Su N-Y, Chase JA, Forschler BT (2001) New termite (Isoptera: Kalotermitidae, Rhinotermitidae) records from Georgia. Journal of Entomological Science 36: 109-113.

Scheffrahn RH, Krecek J, Maharajh B, Chase JA, Mangold JR, Moreno J, and Herrera B (2005) Survey of the termites (Isoptera: Kalotermitidae, Rhinotermitidae, Termitidae) of Nicaragua. Florida Entomologist 88: 549-552.

Scheffrahn RH, Myles T, Krecek J, Maharajh B, Bahder BW, Chase JA, Mangold JR, Nishimura T, Setter R (in press) The Termites (Isoptera) of Guatemala. In: Cano EB, Schuster J (Eds.) Biodiversidad de Guatemala, Volume 2. Universidad del Valle de Guatemala, Guatemala, Guatemala.

Silvestri F (1901) Nota preliminare sui termitidi sud-americani. Bollettino dei $\mathrm{Mu}$ sei di Zoologia ed Anatomia Comparata della R.Università di Torino 16: 1-8. Silvestri F (1903) Contribuzione alla conoscenza dei Termiti e Termitofili dell'America Meridionale. Redia 1: 1-234.

Snyder TE (1925a) New termites and hitherto unknown castes from the Canal Zone, Panama. Journal of Agricultural Research 29: 179-193.

Snyder TE (1925b) New American termites including a new subgenus. Journal of the Washington Academy of Science 15: 152-162.

Snyder TE (1926a) Five new termites from Panama and Costa Rica. Proceedings of the Entomological Society of Washington 28: 7-16.

Snyder TE (1926b) New termites from Guatemala, Costa Rica, and Colombia. Journal of the Washington Academy of Science 16: 18-28.

Snyder TE (1926c) Change of name of Isoptera. Proceedings of the Entomological Society of Washington 28: 51.

Snyder TE (1933) Calcaritermes in the United States. Proceedings of the Entomological Society of Washington 35: 67-69.

Stone WD, Nebeker TE, Monroe WA, MacGown JA (2007) Ultrastructure of the mesonotal mycangium of Xylosandrus mutilatus (Coleoptera: Curculionidae). Canadian Journal of Zoology 85: 232-238. 